\title{
Celebrating 45 Years of the Brazilian Society of Automatics
}

\author{
Vilma A. Oliveira ${ }^{1}$ (D) Luis A. Aguirre ${ }^{2}$ - Lilian K. Carvalho ${ }^{3}$ \\ Received: 7 September 2021 / Revised: 7 September 2021 / Accepted: 13 September 2021 / Published online: 17 October 2021 \\ (c) Brazilian Society for Automatics-SBA 2021
}

\begin{abstract}
The Brazilian Society of Automatics, Sociedade Brasileira de Automatica (SBA) in Portuguese, celebrated its 45th anniversary during the XXIII Congresso Brasileiro de Automática (CBA) in a virtual platform due to the global pandemic of coronavirus COVID-19. In this paper, the authors have summarized its activities since 2002. The previous activities before 2002 were presented in Revista Controle \& Automação da SBA. This magazine became Journal of Control, Automation and Electrical Systems after 2012 published by Springer.
\end{abstract}

Keywords Brazilian automation conference $\cdot$ Technical society $\cdot$ SBA 45 years

\section{Introduction}

The Brazilian Society of Automatics was founded in 1975 (on June 5, 1975, SBA Foundation meeting took place in São Paulo, at the Polytechnic School of the University of São Paulo having Prof. Plìnio B. L. Castrucci as the president and Prof. Celso P. Bottura as the vice-president for the term of 1975-1977) to meet the need for exchange among Brazilian specialists working in the field of Automation and Control. The events leading to the foundation of SBA are described in detail in Pereira and Bottura (2009).

SBA is the National Member Organization (NMO) of IFAC in Brazil and therefore the events of IFAC held in Brazil are IFAC-SBA jointly organized.

The society is led by a Board of Directors, Council and Technical Committees (CTs). In addition to its main conference: the Congresso Brasileiro de Automática (CBA) that had its first edition back in 1976, SBA started organizing two symposia, namely: (i) Simpósio Brasileiro de Automação Inteligente (SBAI) from 1993 and (ii) Simpósio Brasileiro

\footnotetext{
Vilma A. Oliveira

voliveira@usp.br

Luis A. Aguirre

aguirre@ufmg.br

Lilian K. Carvalho

lilian.carvalho@poli.ufrj.br

1 Universidade de São Paulo, São Paulo, Brazil

2 Univeridade Federal de Minas Gerais, Belo Horizonte, Brazil

3 Universidade Federal do Rio de Janeiro, Rio de Janeiro, Brazil
}

de Sistemas Elétricos (SBSE) in 2019, both every other year, thus alternating with CBA. In the current philosophy, SBA TC coordinators have taken on the role of area editors of the official events of SBA, SBA Board of directors since 2004 are listed in Appendix A.

In de Lima (1987); Castrucci and Kaszkurewicz (2002); de Lima and de Lauro Castrucci (2002), the authors presented very well the past 10 and 25 years of SBA and in the 2009 IEEE Conference on the History of Technical Societies, respectively. Carlos Eduardo Pereira, former SBA President, and Celso Pascoli Bottura, former and one of SBA founders, addressed some aspects of the history of SBA emphasizing its beginnings (Pereira and Bottura 2009).

In this paper, the authors summarize SBA activities after 2002 , the 45 th anniversary celebration and the main achievements over the past 20 years.

\section{Activities}

The various editions of CBA have been held across the country. The society has witnessed the growing participation of professionals working in the several areas covered by SBA, coming from various regions of Brazil, as well as from other countries. 
Fig. 1 CBA 2020 virtual entrance hall

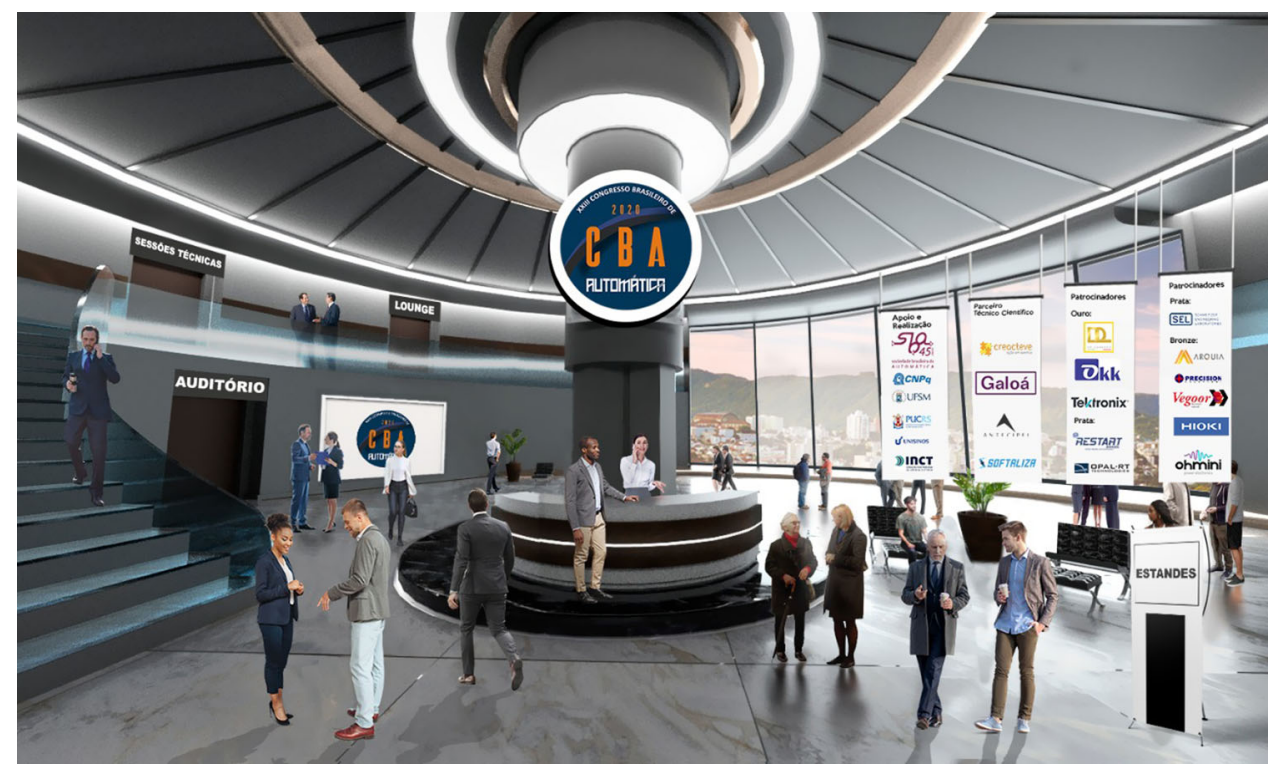

SBA also co-sponsored IFAC events such as:

The 15th IFAC Workshop on Discrete Event Systems (WODES'2020) held in virtual mode 2020 with the presentation of papers and plenaries on line. President João Carlos Basilio.

The 2019 International Summer School on Sliding Mode Control Variable Structure Systems and International Graduate School on Control of European Embedded Control Institute held in Rio de Janeiro, RJ, 2019. Presidents Tiago Roux Oliveira, Jos e Paulo Vilela Soares Cunha and Leonid Fridman.

The 12th IFAC Symposium on Dynamics and Control of Process Systems held in Florian opolis, SC, 2019. President Julio Elias Normey-Rico.

The 9th IFAC Symposium on Robust Control Design (ROCOND'18) and 2nd IFAC Workshop on Linear Parameter Varying Systems (LPVS'18) held in Florianopolis, SC, 2018. National Organizing Committee Chair Eugênio de Bona Castelan.

The 1st International Symposium on Instrumentation Systems, Circuits and Transducers (INSCIT) held in Belo Horizonte, MG, 2016. President Davies William de Lima Monteiro.

The 4th IFAC Symposium on Telematics Application held in Porto Alegre, RS, 2016. President Carlos Eduardo Pereira.

The 1st IFAC Conference on Cyber-Physical \& HumanSystems (CPHS 2016) held in Florianopolis, SC, 2016. National Organizing Committee Chair Ubirajara Franco Moreno.
The 11th IFAC Symposium on Robot Control (SYROCO) held in Salvador, BA, 2015. National Organizing Committee Chair Walter Fetter Lages.

The 3rd IFAC Symposium on System Structure and Control held in Foz do Iguassu, PR, 2007. International Program Chair João Manoel Gomes da Silva Junior.

The 11th IFAC Symposium Information Control Problems in Manufacturing (INCOM 2004) held in Salvador, BH, 2004. President Carlos Eduardo Pereira.

All previous SBA conferences (CBA, SBAI and SBSE) and their presidents since 2002 are listed in Appendix B.

The SBA paid tribute to the memory of the two former active members Prof. Márcio Rillo and Prof. José Luiz Rezende Pereira.

The tribute to the memory of Prof. Márcio Rillo, deceased in May 2010, was paid at a plenary session of the XVIII CBA, held in the city of Bonito, Mato Grosso do Sul. In this plenary session, three former students of Márcio Rillo gave a brief seminar on the topics that most characterized his work: AI Planning, Robotics and Automation. At SBA, he served as the president from 1997-1999 and president of the XII CBA and of two editions of SBAI.

The tribute to the memory of Prof. Josã Luiz Rezende Pereira, deceased in April 2020, was paid at the opening ceremony of the 2020 SBSE held in Santo Andre, southeast of Brazil. As a scientific leader, José Luiz was able to gather people around interesting and relevant projects in the area of power systems. At SBA, he served as chair of the Technical Committee on Power Systems and president of the XV CBA. 


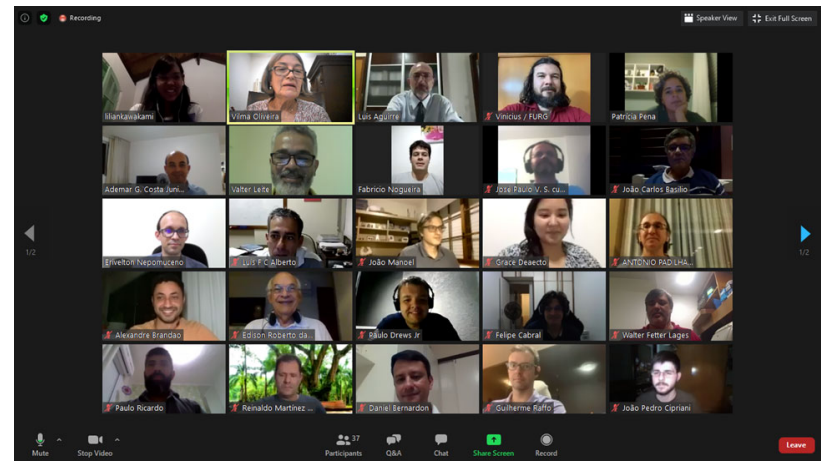

Fig. 2 SBA general assembly during the CBA 2020

\section{The 45th Anniversary During the XXIII CBA}

The XXIII CBA was jointly organized by the Federal University of Santa Maria, the Pontifical Catholic University of Rio Grande do Sul and the Vale do Rio dos Sinos University. Fully in virtual mode, it took place from 23rd to 26th of November 2020 (see the entrance hall in Fig. 1 and a print of the participants of the SBA general assembly in Fig. 2). It is important to say that in this edition we celebrated the 45 years, and that the Brazilian congress of automatics is a consolidated and prestigious both nationally and abroad.

It is a great privilege for the authors of this paper to have been part of SBA board of directors and speak about the CBA success in attracting the scientific and technological communities and industrial partners. Especially in the year of the 45th anniversary of SBA. With partnerships with the industrial sector, CBA 2020 had an outstanding technical program with short courses, plenary sessions, special sessions, discussion panels and technical sessions, with the participation of renowned speakers and the best innovations in the world of engineering. An early desire of SBA has been to establish a closer relationship with industrial sector, thus 'bridging the gap between industry and academia. In that respect, during CBA 2020, SBA's partnership with industry was formally strengthen by hosting the industry panel organized by the newly created SBA industrial committee (Silva and Silva $\left.2021^{1}\right)$.

During the CBA 2020, following the initiative at CBA 2014 and followed at SBAI 2019 to recognize outstanding conference papers, the best student paper awards for undergraduate, master and doctorate categories were granted. This award will further motivate the students to develop their work and consider SBA events to submit their results. We hope to consolidate this initiative in the forthcoming events sponsored by the society.

We also want to add that the SBA Simpósio Brasileiro de Sistemas Elétricos (SBSE 2020) held in September 2020 as

\footnotetext{
1 https://www.blucher.com.br/livro/detalhes/automacao-no-pos-pand emia-1737/engenharias-e-materiais-112
}

a virtual symposium was a success and served as a reference for this virtual event.

Unfortunately, personal contact became more difficult at the time of the COVID-19 pandemic. Hence, during the XXIII edition of CBA, there were no coffee breaks and the much anticipated banquet was postponed to a future event. It was a pity that the 45th anniversary of the society could not be celebrated in that way with colleagues and students.

\section{Past 20 Years}

\subsection{Publications}

The official journal of SBA is the Journal of Control, Automation and Electrical Systems published by Springer since $2013^{2}$. The journal, originally named Controle \& Automação, started in 1987 and its twelve first volumes are freely accessible ${ }^{3}$ and volumes 13 (2002) to 23 (2012) are made available by the Scientific Electronic Library Online ${ }^{4}$. The journal publishes original research papers as well as tutorials pertaining to industrial automation, intelligent systems, robotics, instrumentation, power electronics, power systems and control theory and applications. The internationalization of the SBA journal Controle \& Automação was approved during the 2010-2012 SBA Board of Directors and up to that point all the editorial works were done locally. Prof. José Raimundo de Oliveira played a particularly important role in developing and maintaining an editorial system which was intensively used up to 2012 .

The first four Editors-in-Chief of Controle \& Automação were listed in Castrucci and Kaszkurewicz (2002). The following Editors-in-Chief were:
João Bosco Ribeiro do Val 2000-2004
Ricardo Ribeiro Goodwin 2004-2008
Luis Antonio Aguirre 2008-2012
Ivan Nunes da Silva 2013-2018
Antonio Padilha Feltrin since 2018.

The Proceedings of SBA-sponsored conferences since 2020 are published on the open journal systems (OJS) platform with access through the SBA site ${ }^{5}$.

In 2007 the Society published a three-volume set entitled Enciclopédia de Automática. The motivation was to provide reference material for students, researchers and practitioners from industry in topics related to Control and Automation.

\footnotetext{
2 https://www.springer.com/journal/40313

3 https://www.sba.org.br/revista/

${ }^{4}$ https://www.scielo.br/j/ca/grid

5 https://www.sba.org.br/open_journal_systems/
} 
Luis Aguirre was Editor-in-Chief and nine other editors were invited to organize a part of the Encyclopedia. This effort resulted in 47 chapters written by more than a hundred authors from 27 Brazilian institutions. The index is composed of 2600 entries and the reader will find over 1300 references cited. The three volumes are organized as follows:

1. Volume 1 (Aguirre et al. 2007a) is composed of three parts: Teaching in Control (Augusto Bruciapaglia), Control Theory (Ricardo Takahashi) and Manufacturing (Paulo Miyagi);

2. Volume 2 (Aguirre et al. 2007b) is composed of three parts: Linear Systems (Pedro Peres), Nonlinear Systems (José Roberto Piqueira) and Process Control and Industrial Networks (Carlos Eduardo Pereira);

3. Volume 3 (Aguirre et al. 2007c) is composed of three parts: Estimation and Filtering (Wagner Amaral), Intelligent Systems (Alexandre Alves da Silva) and Robotics (Mario Campos).

Another enterprise put forward by SBA board of directors took place in 2020 with the proposal of creating a publishing house for the society: SBA-Press. From the early days of SBA, some of its founders were actively involved in producing textbooks for teaching control, as surveyed in (Gertler 2006). Hence following a certain subtle tradition, the original motivation was twofold. First and foremost, SBA is eager to serve as a professional reference to young scientists and engineers in the fields covered by SBA, which basically ranges over most topics in Electrical Engineering, and virtually every topic in Control Engineering. It was felt that an effective way of achieving this goal was for SBA to support the publication of undergraduate and graduate textbooks in all such topics. A second motivation is to provide clear and practical benefits to society members. SBA is willing to financially support the publication of textbooks authored by its members. This would shorten the long and often painful path of finding a publisher for textbooks. Hence, SBA decided to serve its members as a mediator, finding a professional publisher and screening the material submitted for publication. This would also relieve the publisher of having to find reviewers for potential textbooks. Once again, SBA found in Editora Blücher the perfect match.

One of the greatest challenges faced by SBA-Press is to find among its members those who are willing to write and publish textbooks. This is effectively done via the CTs. Each CT searches for interested authors and whenever a book proposal is submitted, the CT is responsible for the first and most detailed evaluation after which it is sent to the Editorial Board for further analysis and procedures. At creation, the Editorial Board of SBA-Press was temporarily formed by Luis Aguirre, Ivan Nunes da Silva e Valter Leite.
So far, four books have been approved for publication and the first one is in press at the time of writing this paper (Normey-Rico and Morato 2021).

\subsection{New Committees}

Extending the existing technical committees, Automation, Control, Power Electronics, Electronic Instrumentation, Robotics, Power Systems, Intelligent Systems, the following committees were created to cover new areas and deepen topics relevant to SBA which are the System Identification and Data Science and the Engineering Education Committees.

SBA TCs chairs had their functions expanded with attributions in running the SBA conferences. As of CBA 2018, the TCs chairs consolidated their role as Area Editors, coordinating the entire reviewing process and also indicating invited speakers and webinars sponsored by SBA.

In addition to the TCs, institutional committees were created: (i) Industrial Committee, (ii) SBA Jovem and (iii) SBA Mulheres na Automática. These committees are important to assist the Society transversal activities.

The Industrial Committee aims to foster partnerships between the SBA and industry and promote the participation of researchers from companies in the SBA events by encouraging professionals linked to the industrial sector to get involved in the SBA activities and to propose actions that enable and facilitate the transfer of knowledge from academia to the industrial sector, and vice versa.

SBA Jovem is aimed at promoting and encouraging the membership of young students and professionals to become member of the society.

SBA Mulheres na Automática is aimed at promoting female engineers and scientists and encouraging women of all ages to pursue a career in engineering. As of SBAI 2017, a reception is held at the main technical conferences of the SBA to expand the network of contacts and promote adherence to this committee.

\subsection{SBA Webinars}

SBA Webinars were created to promote exchange of knowledge and experience among SBA members. The webinars cover topics of interest ranging from lectures, workshops to short courses. The idea is to encourage, in particular, young members to participate.

The format of the SBA Webinars was presented in 2020 starting with a visual identity and a standard layout for the presentations. For the Webinar broadcasting, Rede Nacional de Pesquisa ${ }^{6}$ (RNP) platform has been used together with SBA's YouTube channel.

\footnotetext{
${ }^{6}$ https://conferenciaweb.rnp.br/
} 
The first Webinar was sponsored by the Control Technical Committee on the COVID-19 theme and was entitled "Modelos matemáticos para monitorar e prever a propagação de uma epidemia - A iniciativa COVID-19: Observatório Fluminense" by Dr. Américo Cunha Jr from the Universade do Estado do Rio de Janeiro (UERJ). All webinars are available on the SBA site ${ }^{7}$.

\subsection{Cooperation and Collaboration with Academic Societies}

Over the last 20 years, SBA has strengthened its international partnership with the IFAC and other national and international academic associations. For instance, a former President of SBA, Prof. Carlos Eduardo Pereira, is the current Chair of the IFAC Technical Board having also been a member of the IFAC Council after serving for two 3-year terms as Chair of the Technical Committee "Manufacturing Plant Control" and Prof. Reinaldo M. Palhares, a current member of SBA Council, is serving as a member of the IFAC Conference Board. SBA also had the opportunity to appoint Prof. Julio E. Normey-Rico to deliver a Plenary Lecture at IFAC 2020 and to suggest several active SBA members to the IFAC Technical Committees.

SBA is also an institutional member of the International Fuzzy Systems Association (IFSA) and maintains a representative on its Council. After 2019, there was an understating with Sociedade Brasileira de Matematica Aplicada e Computacional (SBMAC) and a joint member SBA-SBMAC was constituted.

Recognizing mutual interests in the field of education and research, SBA and the Associação Portuguesa de Controlo Automatico (APCA), also an IFAC NMO, agreed on the establishment of a Memorandum of Understanding for bilateral cooperation and collaboration.

In relation to the national scenario, SBA participates jointly with the academic community in committees of the Sociedade Brasileira para o Progresso da Ciência (SBPC) to strengthen Brazilian policies for science.

\section{Conclusion}

Looking back 45 years, it becomes clear to most of us that much has been done and that the Brazilian Society of Automatics has not only grown but also, and principally, matured. The number of sponsored events has increased but also the internal organization in terms of the Board of Directors, Council and Technical Committees has adapted to face the overwhelming work. New offices were formed but the most important step taken in recent years was the clear defini-

\footnotetext{
7 https://www.sba.org.br/web/paginas/view?id=44
}

tion of the roles each Technical Committee should play. This matured and successfully tested organization will prove to be a key aspect in order to promote the continuing success of SBA in a most challenging future. In closing, it should be said that the stage at which SBA is at present is the unselfish dedication of many. Our sincere hope is that SBA will indeed become a standard for younger generations.

\section{Declarations}

Conflict of interest The authors declare that they have no conflict of interest.

\section{A 2004-2021 SBA Board of Directors}

The Board of Directors elected since 2002, formed by President, Vice-President, Secretary and Treasurer, were:

2004-2006 Takashi Yoneyama, Luis Antonio Aguirre, Carlos Henrique Costa Ribeiro, Marco Antonio Caetano. 2006-2008 Aldayr Dantas De Araújo, Ramon Romankevicius Costa, Adrião Duarte Dória Neto, Jorge Dantas de Melo.

2008-2010 Carlos Eduardo Pereira, Eugenio Castalan De Bona Neto, João Manoel Gomes Da Silva, Alexandre Sanfelice Bazanella.

2010-2012 José Roberto Castilho Piqueira, Osvaldo Ronald Saavedra Mendez, José Reinaldo da Silva, Ricardo Ribeiro Gudwin.

2013-2014 Marco Henrique Terra, Antonio Marcus Nogueira Lima, Luís Fernando Costa Alberto, João Bosco Augusto London Junior.

2015-2017 Antonio Marcus Nogueira Lima, Osvaldo Ronald Saavedra Mendez, Maria de Fátima Queiroz Vieira, José Sérgio da Rocha Neto, Jés de Jesus Fiais Cerqueira, Sebastian Yuri Cavalcanti Catunda.

2017-2019 Osvaldo Ronald Saavedra Mendez, Alexandre Sanfelice Bazanella, Shigeaki Leite de Lima, Denisson Queiroz Oliveira, Anna Diva Plasencia Lotufo, Luiz Carlos Pereira da Silva.

2019-2021 Vilma Alves de Oliveira, Luis Antonio Aguirre, Lilian Kawakami Carvalho, Luís Fernando Costa Alberto, Ricardo Quadros Machado, Grace Silva Deaecto.

\section{B SBA-Sponsored Conferences}

\section{B.1 Congresso Brasileiro de Automática}

CBA 2020-XXIII CBA, Virtual, Brasil, President Daniel Pinheiro Bernardon. 
CBA 2018-XXII CBA, João Pessoa PB, Brasil, President Edison Roberto Cabral da Silva.

CBA 2016- XXI CBA, Vitória ES, Brasil, President Mário Sarcinelli Filho

CBA 2014-XX CBA, Belo Horizonte MG, Brasil, President Ronaldo Pena.

CBA 2012-XIX CBA, Campina Grande PB, Brasil, President Edison Roberto Cabral da Silva.

CBA 2010-XVIII CBA, Bonito, Mato Grosso do Sul MS, President Antonio Padilha Feltrin.

CBA 2008-XVII CBA, Juiz de Fora, MG, Brasil, President José Luiz R. Pereira.

CBA 2006 XVI CBA, Salvador, BA, Brasil, President Amauri Oliveira.

CBA 2004-XV CBA, Gramado,RS, Brasil, President Carlos Eduardo Pereira.

CBA 2002-XIV CBA, Natal, RN, President Aldayr Dantas de Araújo.

\section{B.2 Simpósio Brasileiro de Automação Inteligente}

SBAI 2021-XV SBAI, FURG, Virtual. Presidents Silvia Silva da Costa Botelho, Paulo Lilles Jorge Drews-Jr and Vinicius Menezes de Oliveira.

SBAI 2019-XIV SBAI, UFOP, Ouro Preto MG. Presidents Marcone Jamilson Freitas Souza and Sandoval Carneiro.

SBAI 2017-XIII SBAI, UFRGS, Porto Alegre RS. President João Manoel Gomes da Silva Jr.

SBAI 2015-XII SBAI, UFRN, Natal RN. Presidents Luiz Affonso Henderson Guedes de Oliveira and Aldayr Dantas de Araújo.

SBAI 2013-XI SBAI, UFC, Fortaleza CE. Presidents Bismark Claure Torrico and Arthur Plínio de Souza Braga. SBAI 2011-X SBAI, UFSJ, São João Del Rei MG. President Erivelton Geraldo Nepomuceno.

SBAI 2009-IX SBAI, UNB, Brasília DF. President Adolfo Bauchspiess.

SBAI 2007-VIII SBAI, UFSC, Florianópolis SC. President Edson Roberto de Pieri.

SBAI 2005-VII SBAI, UFMA, São Luís MA. President Osvaldo Saavedra.

SBAI 2003-VI SBAI, UNESP, Bauru SP. President Marcio Rillo.

SBAI 2001-V SBAI, Hotel Continental, Canela RS. Presidents Carlos Eduardo Pereira and Alexandre Sanfelice Bazanella.

\section{B.3 Simpósio Brasileiro de Sistemas Elétricos}

SBSE 2020-VIII SBSE, UFABC, Santo André, SP. President Alfeu Joãozinho Sguarezi Filho and Antônio Padilha Feltrin

SBSE 2018-VII SBSE, Niterói Hotel, Niterói RJ, Brasil. Presidents Vitor Hugo Ferreira and Marcio Zamboti Fortes.

\section{References}

Aguirre, L. A., Bruciapaglia, A. H., Miyagi, P. E., \& Takahashi, R. H. C. (Eds.). (2007a). In: Enciclopédia de Automática: Controle e Automação (Vol. 1). São Paulo: Editora Blücher.

Aguirre, L. A., Pereira, C. E., Piqueira, J. R. C., \& Peres, P. L. (Eds.). (2007b). In: Enciclopédia de Automática: Controle e Automação (Vol. 2). São Paulo: Editora Blücher.

Aguirre, L. A., Alves da Silva, A. P., Campos, M. F. M., \& Amaral, W. C., (Eds.). (2007c) InL Enciclopèdia de Automàtica: Controle e Automaçõ (Vol. 3). São Paulo: Editora Blücher.

Castrucci, P. L., \& Kaszkurewicz, E. (2002). Os 25 anos da sociedade brasileira de automática. Revista Controle \& Automação, 13, 1-5.

de Lima, W. C. (1987). Os 10 anos de produção científica em auttomação no brasil. SBA: Controle e Automação 1, 3-10.

de Lima, W. C., \& Castrucci, P. L. (2002). Còpia de artigo publicado no volume 1 no. 1 de janeiro de 1987 e còpia do pronunciamento na abertura do I congresso brasileiro de automàtica. SBA: Controle e Automação 13:7-17.

Gertler, J. E. (2006). Historic control textbooks. In: IFAC Symposia Series. Amsterdam: Elsevier Ltd.

Normey-Rico, J. E., \& Morato, M. M. (2021). Introdução ao Controle de Processos. São Paulo: Blücher e SBA-Press.

Pereira, C. E., \& Bottura, C. P. (2009). The brazilian society of automatics ("sociedade brasileira de automatica" - SBA. In: 2009 IEEE Conference on the History of Technical Societies, pp. 1-6.

Silva, J. R., \& Silva, J. M. (2021). Automação no Pós-Pandemia: Painel industrial. São Paulo: Blücher Open Access

Publisher's Note Springer Nature remains neutral with regard to jurisdictional claims in published maps and institutional affiliations. 